\title{
ANALISIS EKSISTENSI TRAVELLING WAVE PADA MODEL SIR PENYEBARAN PENYAKIT COVID-19 DENGAN MENGGUNAKAN PERSAMAAN DIFUSI
}

\section{Analysis of the Existence of Travelling Wave on the SIR Model of the Spread of Covid- 19 Disease Using the Equation of Diffusion}

\author{
Safhira Sekar Euchalypta ${ }^{1}$, Irma Fitria ${ }^{2}$, Nashrul Millah ${ }^{3 *}$ \\ 1,2 Prodi Matematika, Jurusan Matematika dan Teknologi Informasi, Institut Teknologi Kalimantan \\ Jl. Soekarno Hatta KM.15, Balikpapan, 76127, Indonesia
}

Corresponding author e-mail: ${ }^{3 *}$ nashrulmillah53@gmail.com

\begin{abstract}
Abstrak
Penyebaran penyakit COVID-19 dari satu daerah menuju daerah lain menyebabkan travelling wave dapat terjadi. Penelitian ini akan menyelidiki eksistensi travelling wave pada penyebaran penyakit COVID-19 menggunakan model epidemi sederhana dengan 3 (tiga) variabel, dimana Susceptible $(S)$, Infected (I), dan Recovery $(R)$. Analisis eksistensi travelling wave dilakukan dengan cara linierisasi model pada persekitaran dua titik tetap model SIR untuk mendapatkan kecepatan minimal penyebaran penyakit. Hasil dari penelitian ini menemukan bahwa penyebaran penyakit COVID-19 antar daerah cukup cepat terjadi pada titik tetap bebas penyakit jika terdapat infeksi dari luar dengan kecepatan minimal penyebaran penyakit sekitar 10,621 $\mathrm{km} /$ hari, sehingga travelling wave dapat terjadi.
\end{abstract}

Kata Kunci: COVID-19, Model, Travelling Wave

\begin{abstract}
The spread of COVID-19 from one area to another causes a travelling wave to occur. This research will investigate the existence of the travelling wave on the spread of COVID-19 disease by using simple epidemiological model with 3 (three) variables, where Susceptible $(S)$, Infected $(I)$, and Recovery $(R)$. The analysis of the existence of travelling waves is carried out by linearizing the model around two fixed points of the SIR model to obtain the minimum speed of disease spread. The results of this research found that the spread of COVID-19 disease between regions was quite fast at a fixed point free of disease if there was an infection from outside, with a minimum speed of spreading the disease around 10,621 km/day, so travelling waves could happen.
\end{abstract}

Keyword: COVID-19, Model, Travelling Wave

Submitted:12 $2^{\text {th }}$ April $2021 \quad$ Accepted: 02 $2^{\text {nd }}$ August 2021

How to cite this article:

S. S. Euchalypta, I. Fitria, and N. Millah, “ANALISIS EKSISTENSI TRAVELLING WAVE PADA MODEL SIR PENYEBARAN PENYAKIT COVID-19 DENGAN MENGGUNAKAN PERSAMAAN DIFUSI”, BAREKENG: J. Il. Mat. \& Ter., vol. 15 no. 03, pp. 513-524, Sep. 2021. 


\section{PENDAHULUAN}

Virus korona sebenarnya sudah mulai diidentifikasi pada pertengahan tahun 1960-an. Namun, virus korona saat itu, secara umum, hanya menyebabkan demam biasa [12]. Kemudian pada akhir tahun 2019, China mengalami wabah virus korona baru yang menewaskan lebih dari 1.800 orang dan menginfeksi lebih dari 70.000 orang dalam kurun waktu 50 hari pertama epidemi [10]. Wabah virus korona baru ini ditemukan oleh dr. Zhang Jixian, dimana virus tersebut diberi nama SARS-CoV-2 serta penyakitnya bernama Penyakit Coronavirus 2019 (COVID-19). Virus SARS-CoV-2 mempunyai rata-rata periode inkubasi sekitar 5.1 sampai 5.8 hari dan mulai menunjukkan gejala sekitar 11.5 sampai 15.6 hari. Penyakit COVID-19 menyebar menuju berbagai dunia yang kemudian wabah ini disebut pandemi COVID-19. Penyakit ini, terkonfirmasi pertama kali di Indonesia pada tanggal 2 Maret 2020 dan menjadi pandemi pada pertengahan bulan Mei 2020 yang mana angka pasien terinfeksi sudah mencapai 15.000 orang. Penyakit ini menyebar melalui kontak antar manusia, terutama melalui percikan pernafasan (droplet) yang dihasilkan ketika batuk atau bersin $[1,9,11$, $15]$.

Penyebaran penyakit dalam dunia matematika dapat diimplementasikan kedalam pemodelan matematika terutama penyebaran penyakit COVID-19. Dasar dalam menyusun model penyebaran penyakit adalah model SIR dengan mengelompokkan individu-individu kedalam beberapa populasi berdasarkan perilaku dari masing-masing populasi [14]. Model SIR yang digunakan terdiri dari populasi Susceptible (kelas yang rentan penyakit), populasi Infected (kelas yang terinfeksi penyakit) dan populasi Recovery (kelas yang pulih dari penyakit) [2].

Model matematika penyebaran penyakit COVID-19 merupakan representasi bahwa adanya penyebaran penyakit dari satu wilayah menuju wilayah yang lain. Hal tersebut memungkinkan penyebaran penyakit COVID-19 dapat meluas ke berbagai wilayah dan travelling wave dapat terjadi [13]. Oleh karena itu, pada penelitian ini diadakan analisis travelling wave pada model penyebaran penyakit COVID-19. Namun, perlu diperhatikan bahwa dalam menganalisis eksistensi travelling wave yang digunakan hanya persamaan pada populasi terinfeksi saja, dikarenakan adanya interaksi langsung antara populasi rentan dengan populasi terinfeksi dan menyebabkan penyebaran penyakit COVID-19 semakin meluas [4].

\section{METODE PENELITIAN}

Adapun langkah-langkah yang dilakukan dalam penelitian ini:

1. Menentukan Model Penyebaran Penyakit COVID-19

Model yang digunakan dalam penelitian ini adalah model SIR yang berasal dari paper karya Arief Fatchul Huda (2020) dengan judul "Analisis Pengaruh Social Distancing pada Transmisi COVID-19 dengan Menggunakan Model SIR". Penelitian tersebut melibatkan tiga kompartemen dalam suatu populasi tertutup, yaitu susceptible (sehat tapi rentan), infected (positif terinfeksi), dan recovery (sembuh).

\section{Pembentukan Model Travelling Wave}

Setelah mendapatkan model SIR dari penyebaran penyakit COVID-19, dari model SIR tersebut akan dibentuk model baru berdasarkan travelling wave yang terjadi.

\section{Analisis Eksistensi Travelling Wave}

Setelah didapatkan model baru berdasarkan travelling wave maka akan dilakukan analisis untuk membuktikkan eksistensi dan nilai traveling wave pada sistem. Tujuannya adalah untuk mengetahui seberapa cepat dan luas seberapa penyebaran penyakit COVID-19.

4. Simulasi Numerik

Simulasi dilakukan secara numerik dengan menggunakan aplikasi MATLAB. Tujuan dilakukannya simulasi adalah untuk mempermudah pengamatan travelling wave pada sistem yang ada. 


\section{HASIL DAN PEMBAHASAN}

\subsection{Model Penyebaran Penyakit COVID-19}

Pada penelitian ini, model yang digunakan merujuk pada model penyebaran penyakit yang berasal dari paper karya Huda (2020) dengan judul "Analisis Pengaruh Social Distancing pada Transmisi COVID-19 dengan Menggunakan Model SIR" yang kemudian dimodifikasi. Penelitian tersebut melibatkan tiga kompartemen dalam suatu populasi tertutup yaitu: susceptible (sehat tapi rentan), infected (positif terinfeksi), dan recovery (sembuh). Berikut adalah model penyebaran penyakit COVID-19 yang sudah dimodifikasi:

$$
\begin{aligned}
& \frac{d S}{d t}=A-m b S I-\mu S \\
& \frac{d I}{d t}=m b S I-\rho I-\gamma I \\
& \frac{d R}{d t}=\rho I-\mu R
\end{aligned}
$$

dimana $A$ merupakan laju rekrutmen, $m$ merupakan peluang kontak terjadi, $b$ merupakan peluang banyaknya kontak terjadi, $\rho$ merupakan laju kesembuhan, $\mu$ merupakan laju kematian alami pada kompartemen $S$ dan $R$ yang bernilai sama, dan $\gamma$ merupakan laju kematian pada kompartemen $I$ akibat penyakit.

Dalam penelitian yang dilakukan oleh Huda (2020), didapatkan titik tetap dari Persamaan (1). Titik tetap yang didapatkan, yaitu titik tetap bebas penyakit (Disease Free Equilibrium) dan titik tetap endemik penyakit (Endemic Equilibrium) sebagai berikut:

$$
\begin{aligned}
& D F E=(S, I, R)=\left(\frac{A}{\mu}, 0,0\right) \\
& E E=\left(S^{*}, I^{*}, R^{*}\right)=\left(\frac{(\rho+\gamma)}{m b}, \frac{A m b-\mu(\rho+\gamma)}{m b(\rho+\gamma)}, \frac{\rho(A m b-\mu(\rho+\gamma))}{m b(\rho+\gamma) \mu}\right)
\end{aligned}
$$

dengan syarat eksis yaitu $A m b>\mu(\rho+\gamma)[5]$.

\subsection{Analisis Eksistensi Travelling Wave}

Langkah awal dalam menganalisis eksistensi travelling wave adalah dengan membentuk persamaan travelling wave dimana dengan menambahkan persamaan difusi yang mempunyai bentuk umum sebagai berikut :

$$
\frac{\partial u}{\partial t}=D \frac{\partial^{2} u}{\partial x^{2}}
$$

dengan $D \frac{\partial^{2} u}{\partial x^{2}}$ menunjukkan reaksi difusi [8]. Persamaan (5) akan ditambahkan kedalam Persamaan (1) sebagai berikut:

$$
\begin{aligned}
& \frac{\partial S}{\partial t}=D_{S} \frac{\partial^{2} S}{\partial x^{2}}+A-m b S I-\mu S \\
& \frac{\partial I}{\partial t}=D_{I} \frac{\partial^{2} I}{\partial x^{2}}+m b S I-\rho I-\gamma I \\
& \frac{\partial R}{\partial t}=D_{R} \frac{\partial^{2} R}{\partial x^{2}}+\rho I-\mu R
\end{aligned}
$$

Namun, perlu diperhatikan batas dari penelitian hanyalah pada individu terinfeksi saja, dikarenakan penyebaran penyakit COVID-19 dapat terjadi karena adanya kontak langsung antara individu yang rentan dengan individu terinfeksi.

Langkah selanjutnya adalah dengan membentuk $I(u)$ dimana $u(x, t)=x-c t$. Pembentukkan $I(u)$ dilakukan dengan substitusi $u$ pada Persamaan (7) dikarenakan terdapat pembatasan penelitian hanya pada individu terinfeksi saja, sehingga didapatkan sebagai berikut: 


$$
-c \frac{\partial I}{\partial u}=D_{I} \frac{\partial^{2} I}{\partial u^{2}}+m b S I-\rho I-\gamma I
$$

Persamaan (9) adalah persamaan yang akan dilinearisasi dengan menggunakan titik tetap yang telah didapatkan. Tahap terakhir dari analisis eksistensi travelling wave pada Persamaan (9) adalah menentukan kecepatan minimal pada sistem.

Penyelesaian travelling wave dengan kecepatan $c$ pada Persamaan (6), (7), dan (8) adalah penyelesaian yang memiliki bentuk $I(x, t)=I(x-c t)$ dan berhubungan dengan titik kesetimbangan bebas penyakit dan titik kesetimbangan endemik sedemikian hingga berlaku jika $u=x-c t$ maka $\lim _{u \rightarrow-\infty} I=I^{*}$ atau menuju titik tetap kesetimbangan endemik penyakit dan $\lim _{u \rightarrow \infty} I=0$ atau menuju titik tetap bebas penyakit [3].

\subsubsection{Travelling Wave di Sekitar Titik Tetap Bebas Penyakit}

Adapun titik tetap bebas penyakit seperti pada Persamaan (3). Langkah selanjunya adalah mengubah Persamaan (9) ke dalam bentuk linier dengan substitusi titik tetap bebas penyakit terhadap Persamaan (9) maka didapatkan sebagai berikut:

$$
-c \frac{\partial I}{\partial u}=D_{I} \frac{\partial^{2} I}{\partial u^{2}}+\left(\frac{m b A}{\mu}-\rho-\gamma\right) I
$$

Kemudian, mencari solusi untuk persamaan diferensial dengan memisalkan $I=e^{\delta u}$ merupakan penyelesaian pada Persamaan (10) sedemikian hingga diperoleh $I=e^{\delta u}, \frac{\partial I}{\partial u}=\delta e^{\delta u}$, dan $\frac{\partial^{2} I}{\partial u^{2}}=\delta^{2} e^{\delta u}$ yang akan disubstitusikan pada Persamaan (10) sebagai berikut:

$$
-c \delta e^{\delta u}=D_{I} \delta^{2} e^{\delta u}+\left(\frac{m b A}{\mu}-\rho-\gamma\right) e^{\delta u}
$$

karena $e^{\delta u} \neq 0$, maka untuk Persamaan (11) dilakukan perhitungan sebagai berikut:

$$
\begin{aligned}
D_{I} \delta^{2} e^{\delta u}+c \delta e^{\delta u}+\left(\frac{m b A}{\mu}-\rho-\gamma\right) e^{\delta u} & =0 \\
e^{\delta u}\left[D_{I} \delta^{2}+c \delta+\left(\frac{m b A}{\mu}-\rho-\gamma\right)\right] & =0 \\
D_{I} \delta^{2}+c \delta+\left(\frac{m b A}{\mu}-\rho-\gamma\right) & =0
\end{aligned}
$$

Setelah didapatkan Persamaan (12), tahap selanjutnya adalah mencari kecepatan minimal berdasarkan persamaan berikut:

$$
f(\delta)=D_{I} \delta^{2}+c \delta+\left(\frac{m b A}{\mu}-\rho-\gamma\right)=0
$$

di mana, titik kritis dari Persamaan (13) dapat diperoleh dengan $\frac{d f}{d \delta}=0$ sedemikian hingga menjadi sebagai berikut:

$$
\begin{aligned}
\frac{d f}{d \delta}=2 D_{I} \delta+c & =0 \\
\delta & =\frac{-c}{2 D_{I}}
\end{aligned}
$$

Kemudian, substitusi nilai $\delta$ kedalam Persamaan (12) dan diperoleh hasil sebagai berikut:

$$
D_{I} \frac{c^{2}}{4 D_{I}^{2}}-\frac{c^{2}}{2 D_{I}}+\left(\frac{m b A}{\mu}-\rho-\gamma\right)=0
$$




$$
\begin{aligned}
\frac{c^{2}}{4 D_{I}}-\frac{c^{2}}{2 D_{I}}+\left(\frac{m b A}{\mu}-\rho-\gamma\right)=0 \\
-\frac{c^{2}}{4 D_{I}}+\left(\frac{m b A}{\mu}-\rho-\gamma\right)=0
\end{aligned}
$$

Berdasarkan Persamaan (14) dapat diperolah kecepatan minimal dari populasi terinfeksi $\left(c_{I}\right)$ yang akan menghasilkan sebuah gelombang penyebaran penyakit COVID-19 sebagai berikut:

$$
c_{I}=2 \sqrt{D_{I}\left[\frac{m b A}{\mu}-\rho-\gamma\right]}
$$

di mana kecepatan minimal yang diperoleh akan menunjukkan bahwa ada kemungkinan gelombang penyebaran penyakit yang terbentuk.

\subsubsection{Travelling Wave di Sekitar Titik Tetap Endemik Penyakit}

Adapun titik tetap endemik penyakit seperti pada Persamaan (4). Dengan menggunakan cara yang sama seperti pada titik tetap bebas penyakit, yaitu mengubah Persamaan (9) ke dalam bentuk linier dengan substitusi titik tetap endemic penyakit terhadap Persamaan (9) maka didapatkan sebagai berikut:

$$
\begin{aligned}
& -c \frac{\partial I}{\partial u}=D_{I} \frac{\partial^{2} I}{\partial u^{2}}+\left(m b\left(\frac{\rho+\gamma}{m b}\right)-\rho-\gamma\right) I \\
& -c \frac{\partial I}{\partial u}=D_{I} \frac{\partial^{2} I}{\partial u^{2}}
\end{aligned}
$$

Kemudian, mencari solusi untuk persamaan diferensial dengan memisalkan $I=e^{\delta u}$ merupakan penyelesaian pada Persamaan (16) sedemikian hingga diperoleh $I=e^{\delta u}, \frac{\partial I}{\partial u}=\delta e^{\delta u}$, dan $\frac{\partial^{2} I}{\partial u^{2}}=\delta^{2} e^{\delta u}$ yang akan disubstitusikan pada Persamaan (16) sebagai berikut:

$$
-c \delta e^{\delta u}=D_{I} \delta^{2} e^{\delta u}
$$

karena $e^{\delta u} \neq 0$, maka untuk Persamaan (17) dilakukan perhitungan sebagai berikut:

$$
\begin{aligned}
D_{I} \delta^{2} e^{\delta u}+c \delta e^{\delta u} & =0 \\
e^{\delta u}\left[D_{I} \delta^{2}+c \delta\right] & =0 \\
D_{I} \delta^{2}+c \delta & =0
\end{aligned}
$$

Setelah didapatkan Persamaan (18), langkah selanjutnya adalah mencari kecepan minimal berdasarkan persamaan berikut:

$$
g(\delta)=D_{I} \delta^{2}+c \delta
$$

di mana, titik kritis dari Persamaan (19) dapat diperoleh dengan $\frac{d g}{d \delta}=0$ sedemikian hingga menjadi sebagai berikut:

$$
\begin{aligned}
\frac{d f}{d \delta}=2 D_{I} \delta+c & =0 \\
\delta & =\frac{-c}{2 D_{I}}
\end{aligned}
$$

Kemudian, substitusi nilai $\delta$ kedalam Persamaan (19) dan diperoleh hasil sebagai berikut:

$$
D_{I} \frac{c^{2}}{4 D_{I}^{2}}-\frac{c^{2}}{2 D_{I}}=0
$$




$$
\begin{aligned}
\frac{c^{2}}{4 D_{I}}-\frac{c^{2}}{2 D_{I}} & =0 \\
-\frac{c^{2}}{4 D_{I}} & =0
\end{aligned}
$$

Berdasarkan Persamaan (20) dapat diperoleh kecepatan minimal dari populasi terinfeksi $\left(c_{I}^{*}\right)$ yang akan menghasilkan sebuah gelombang penyebaran penyakit COVID-19 sebagai berikut:

$$
c_{I}^{*}=0
$$

di mana kecepatan minimal yang diperoleh akan menunjukkan bahwa ada atau tidak kemungkinan gelombang penyebaran penyakit yang terbentuk.

\subsection{Simulasi Numerik}

Model travelling wave pada Persamaan (6), (7), dan (8) akan diselesaikan secara numerik menggunakan metode Forward Time Centered Space (FTCS) adalah metode beda hingga yang umum digunakan pada pemecahan numerik persamaan diferensial parsial yang mana digunakan untuk mencari pendekatan solusi dari model travelling wave. Metode ini memisalkan $u(x, t)$ merupakan solusi dari suatu persamaan difusi satu dimensi, maka aproksimasi untuk perubahan $u$ terhadap waktu (time) menggunakan pendekatan beda maju (forward time difference) dan perubahan $u$ terhadap jarak (space) menggunakan pendekatan beda tengah (centered space difference) $[6,7]$.

Simulasi model travelling wave ini menggunakan syarat awal Dirichlet di mana pada waktu awal atau $t_{\text {awal }}=1$ berlaku $I(21,1)=I_{0}$, di mana pada posisi ke-21 diasumsikan sebagai titik pusat penyebaran penyakit COVID-19 dan hanya pada posisi tersebut yang menggunakan nilai awal dari populasi $I$ serta sisanya menggunakan nilai awal 0 (nol). Hal tersebut dilakukan untuk memperlihatkan dengan jelas proses difusi pada model. Selanjutnya, syarat batas yang digunakan adalah syarat batas Neumann, sedemikian hingga:

$$
\frac{\partial I(0, t)}{\partial t}=\frac{\partial I\left(N_{x}, t\right)}{\partial t}=0
$$

Adapun parameter yang digunakan dalam simulasi ini akan ditunjukkan pada Tabel 1 sebagai berikut:

Tabel 1. Nilai Parameter

\begin{tabular}{cccc}
\hline Parameter & Nilai & Keterangan & Satuan \\
\hline $\boldsymbol{A}$ & 1 & Berdasarkan asumsi & Orang/hari \\
\hline $\boldsymbol{m}$ & 0.75 & Berdasarkan asumsi & $1 /$ hari \\
\hline $\boldsymbol{b}$ & 0.005 & Berdasarkan asumsi & $1 /$ orang \\
\hline $\boldsymbol{\gamma}$ & 0.096 & Berdasarkan asumsi & $1 /$ hari \\
\hline $\boldsymbol{\mu}$ & 0.086 & Berdasarkan asumsi & $1 /$ hari \\
\hline $\boldsymbol{D}_{\boldsymbol{S}}=\boldsymbol{D}_{\boldsymbol{I}}=\boldsymbol{D}_{\boldsymbol{R}}$ & $1 /(60 \times 360)$ & Berdasarkan asumsi & $1 /$ hari \\
\hline
\end{tabular}

Berdasarkan nilai parameter pada Tabel 1, maka dapat diperoleh nilai dari masing-masing titik tetap dan kecepatan minimal dari populasi terinfeksi di sekitar titik tetap pada Tabel 2 sebagai berikut: 
Tabel 2 Nilai Titik Tetap dan Kecepatan Minimal Populasi Terinfeksi

\begin{tabular}{lcc}
\hline \multicolumn{1}{c}{ Keterangan } & Nilai & Satuan \\
\hline Titik Tetap Bebas Penyakit $(S, I, R)$ & $(21600,0,0)$ & - \\
\hline Titik Tetap Endemik Penyakit $\left(S^{*}, I^{*}, R^{*}\right)$ & $(48.533,5.4822,11367.81)$ & \\
\hline $\begin{array}{l}\text { Kecepatan Minimal Populasi Terinfeksi } \\
\text { di Sekitar Titik Tetap Bebas Penyakit } \\
\left(c_{I}\right)\end{array}$ & 10.621 & $\mathrm{~km} / \mathrm{hari}$ \\
\hline $\begin{array}{l}\text { Kecepatan Minimal Populasi Terinfeksi } \\
\text { di Sekitar Titik Tetap Endemik Penyakit } \\
\left(c_{I}^{*}\right)\end{array}$ & 0 & $\mathrm{~km} / \mathrm{hari}$ \\
\hline
\end{tabular}

Kemudian dilakukan simulasi untuk model SIR penyebaran penyakit COVID-19 dengan menggunakan nilai parameter pada Tabel 1 serta dengan menggunakan nilai awal $S(0)=95, I(0)=5$, dan $R(0)=0$ maka diperoleh hasil simulasi sebagai berikut:

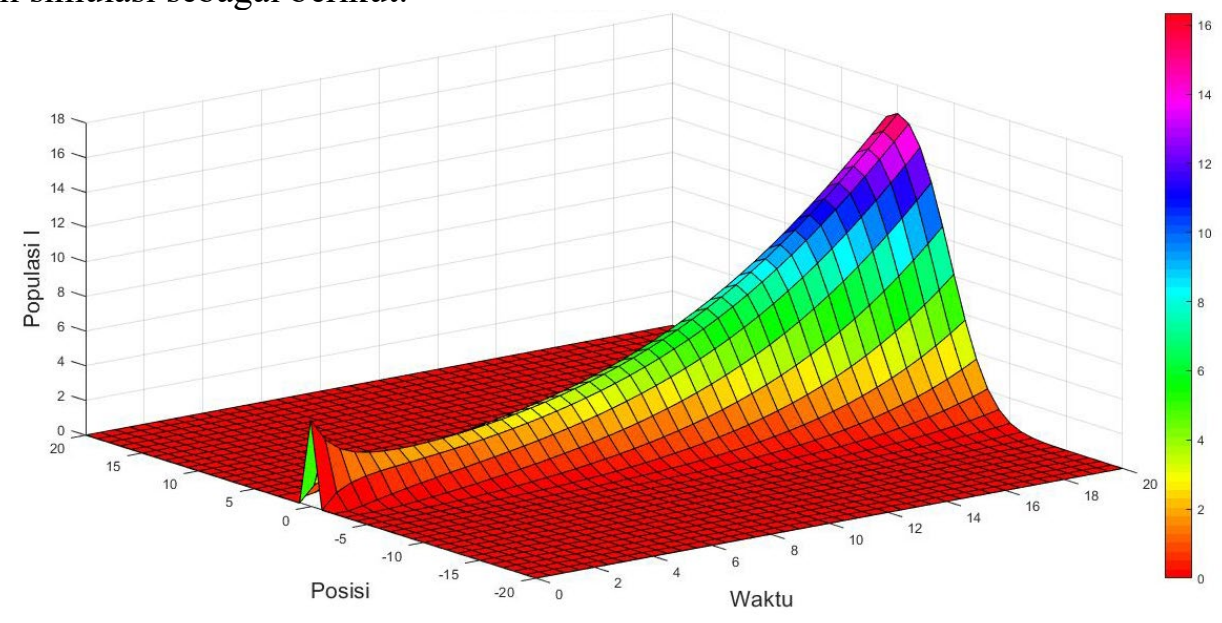

Gambar 1 Simulasi Travelling Wave Saat $0 \leq t \leq 20$

Berdasarkan Gambar 1, dapat terlihat daerah yang bebas penyakit, yaitu daerah yang tidak memiliki populasi terinfeksi atau pada saat $I(0)=0$, di mana semakin jauh dari pusat penyebaran penyakit COVID19 maka akan semakin kecil atau tidak ada penyebaran penyakit COVID-19 pada daerah tersebut. Namun hal tersebut menyebabkan daerah bebas penyakit akan sangat mudah terjangkit penyakit COVID-19 jika terdapat infeksi dari luar daerah, sehingga dapat dengan mudah membentuk gelombang penyebaran penyakit dan menyebabkan penyebaran penyakit COVID-19 akan semakin cepat menyebar antar daerah serta menyebabkan travelling wave terjadi. Oleh karena itu, kecepatan minimal populasi terinfeksi di sekitar titik tetap bebas penyakit adalah $10.621 \mathrm{~km} /$ hari yang artinya kecepatan penyebaran penyakit COVID-19 pada daerah bebas penyakit cukup cepat jika terdapat infeksi dari luar daerah dan menyebabkan peningkatan populasi terinfeksi yang signifikan seperti pada Gambar 1.

Adapun hasil simulasi jika interval waktu pada Gambar 1 diperpanjang sebagai berikut: 


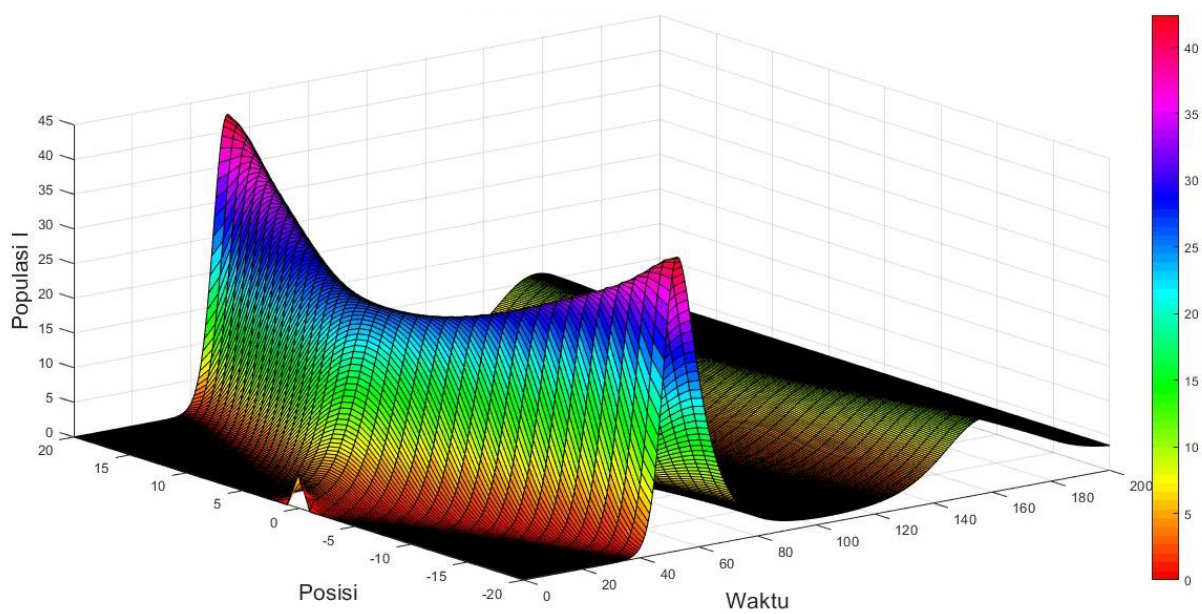

Gambar 2 Simulasi Travelling Wave Saat $0 \leq t \leq 200$

Jika interval waktu diperpanjang, pada daerah tersebut sudah tidak bebas penyakit artinya populasi terinfeksi sudah mulai meningkat dan menyebar menuju berbagai daerah. Adapun penggambaran lebih jelas mengenai peningkatan populasi terinfeksi terhadap waktu seperi yang akan ditunjukkan pada Gambar 3 sebagai berikut:

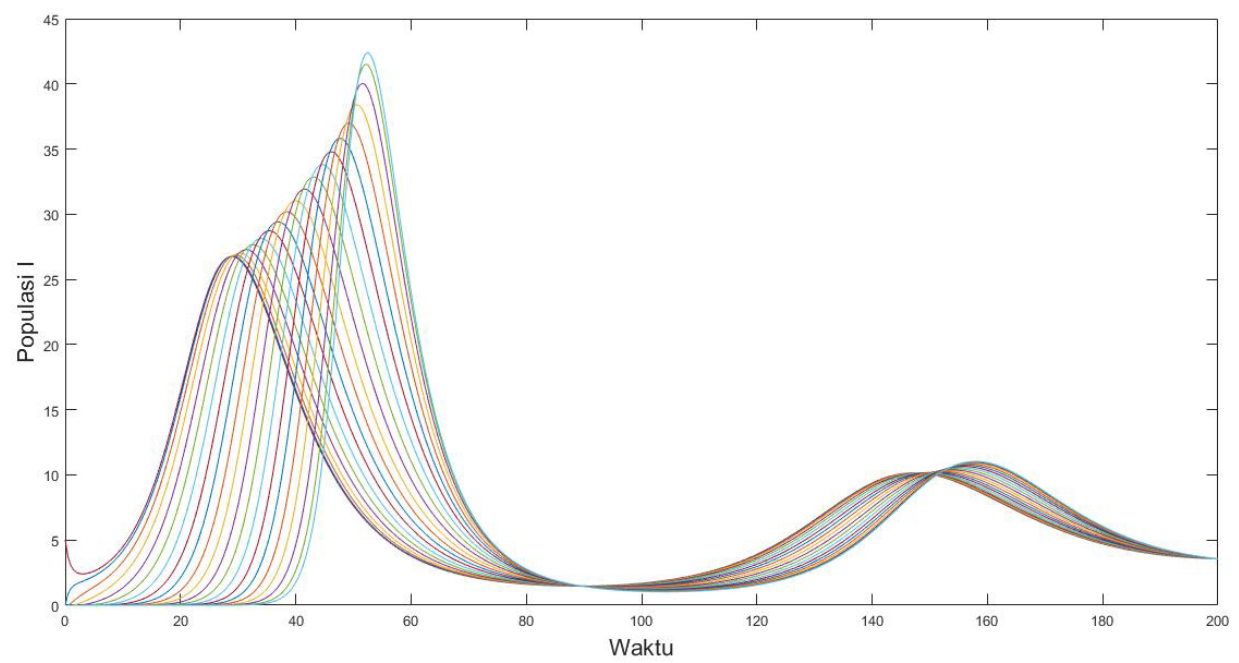

Gambar 3 Peningkatan Populasi Terinfeksi Terhadap Waktu pada Saat $0 \leq t \leq 200$

Semakin panjang waktu yang digunakan dalam simulasi, maka akan terlihat bahwa populasi terinfeksi akan menuju titik kesetimbangan endemik penyakit. Hal tersebut mempengaruhi kecepatan penyebaran penyakit COVID-19 pada setiap daerah di mana semakin menuju daerah endemik penyakit, kecepatan penyebaran penyakit COVID-19 akan cenderung lebih lambat dibandingkan dengan daerah bebas penyakit. Adapun penggambaran peningkatan populasi terinfeksi dengan interval waktu yang diperpanjang sebagai berikut: 


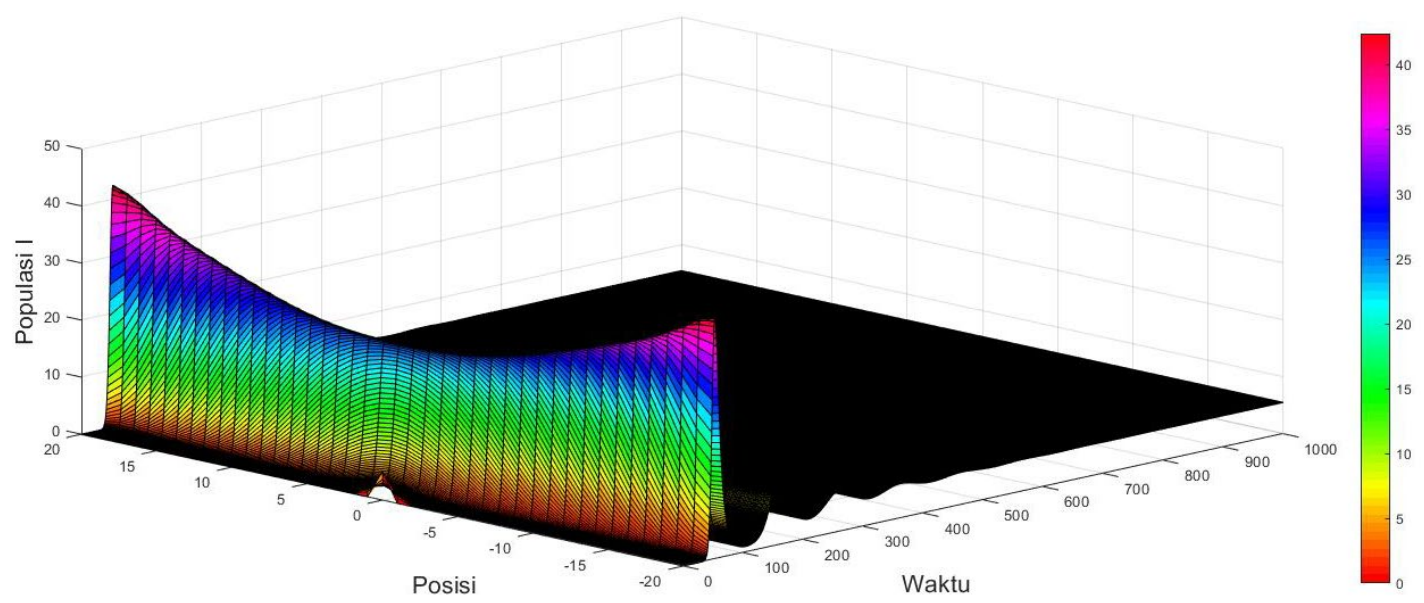

Gambar 4 Simulasi Travelling Wave Saat $0 \leq t \leq 1000$

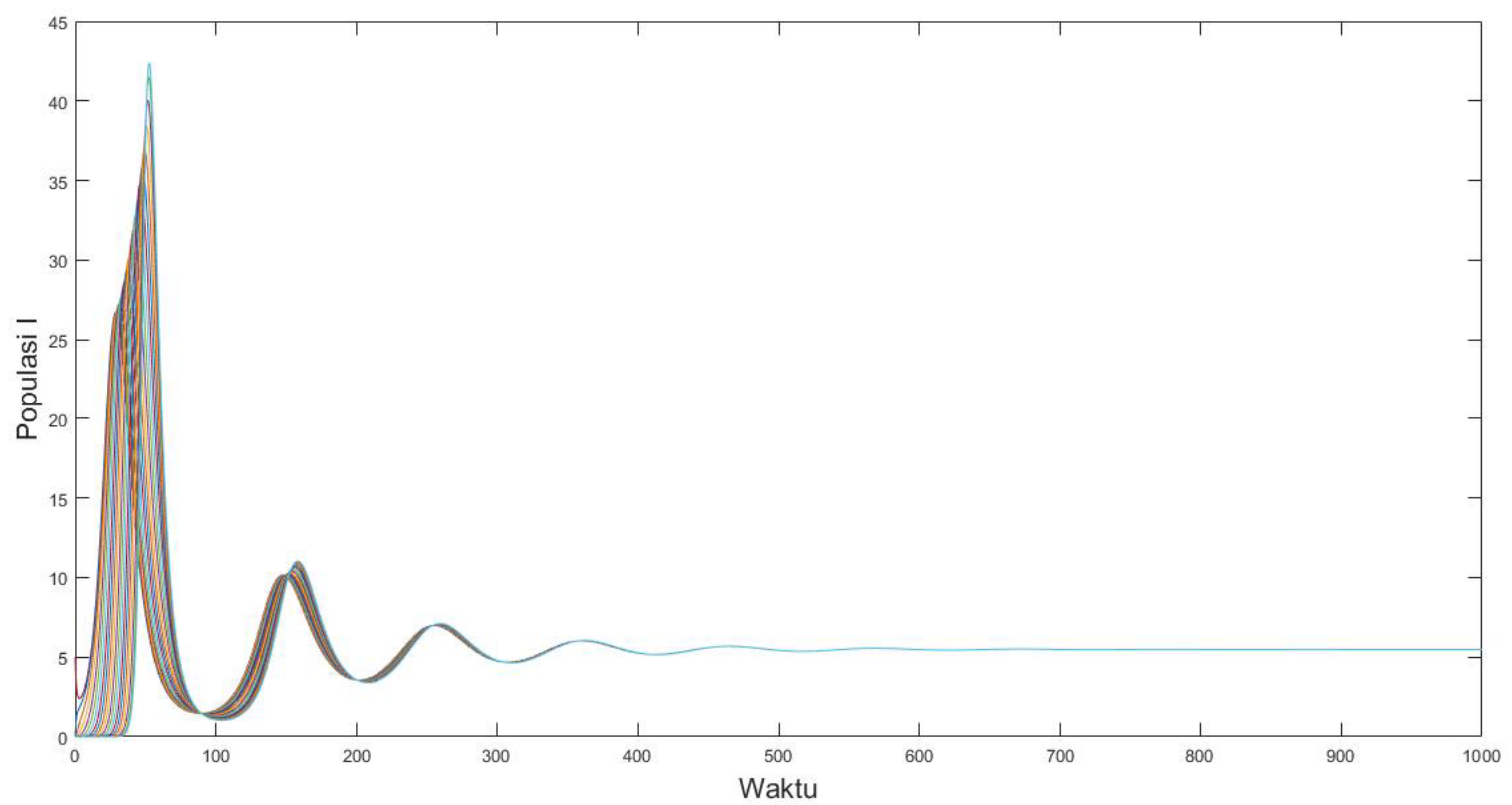

Gambar 5 Peningkatan Populasi Terinfeksi Terhadap Waktu pada Saat $0 \leq t \leq 1000$

Berdasarkan Gambar 5, saat menuju titik kesetimbangan endemik penyakit di mana merupakan daerah endemik penyakit, tidak terlihat adanya penyebaran penyakit COVID-19 antar daerah atau dapat dikatakan tidak terjadi travelling wave yang mana merupakan gelombang penyebaran penyakit antar daerah. Hal tersebut dapat ditunjukkan pada daerah endemik penyakit, jumlah individu terinfeksi cenderung sama pada setiap daerah sehingga tidak terjadi penyebaran penyakit COVID-19. Oleh karena itu, kecepatan minimal dari populasi terinfeksi di sekitar titik tetap endemik penyakit adalah $0 \mathrm{~km} / \mathrm{hari}$ dikarenakan tidak ada penyebaran penyakit COVID-19 antar daerah.

Berdasarkan simulasi yang dilakukan diasumsikan penyebaran penyakit COVID-19 menyebar di suatu daerah pada tanggal 1 Maret 2020. Penyebaran penyakit COVID-19 berada dipuncak penyebaran pada hari ke-53 yang mana jika terhitung dari tanggal 1 Maret 2020 maka akan mencapai puncak penyebaran penyakit COVID-19 pada tanggal 22 April 2020. Kemudian, penyebaran antar daerah mulai berhenti yaitu kurang lebih pada hari ke-510, sehingga jika penyebaran penyakit COVID-19 di Indonesia mulai menyebar pada tanggal 1 Maret 2020 maka diperkirakan akan mulai berhenti menyebar antar daerah pada tanggal 22 Juli 2021. Penggambaran lebih jelas dapat dilihat sebagai berikut: 


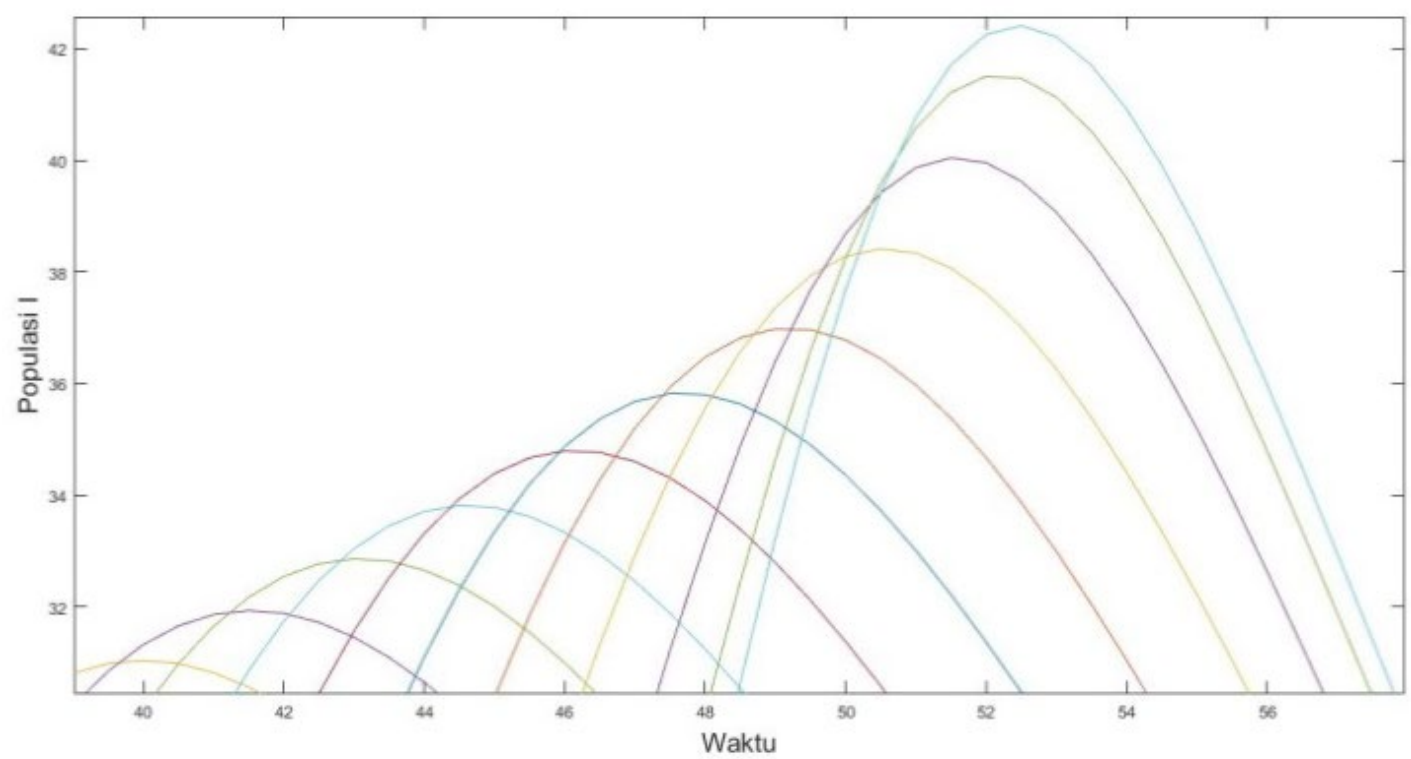

(a)

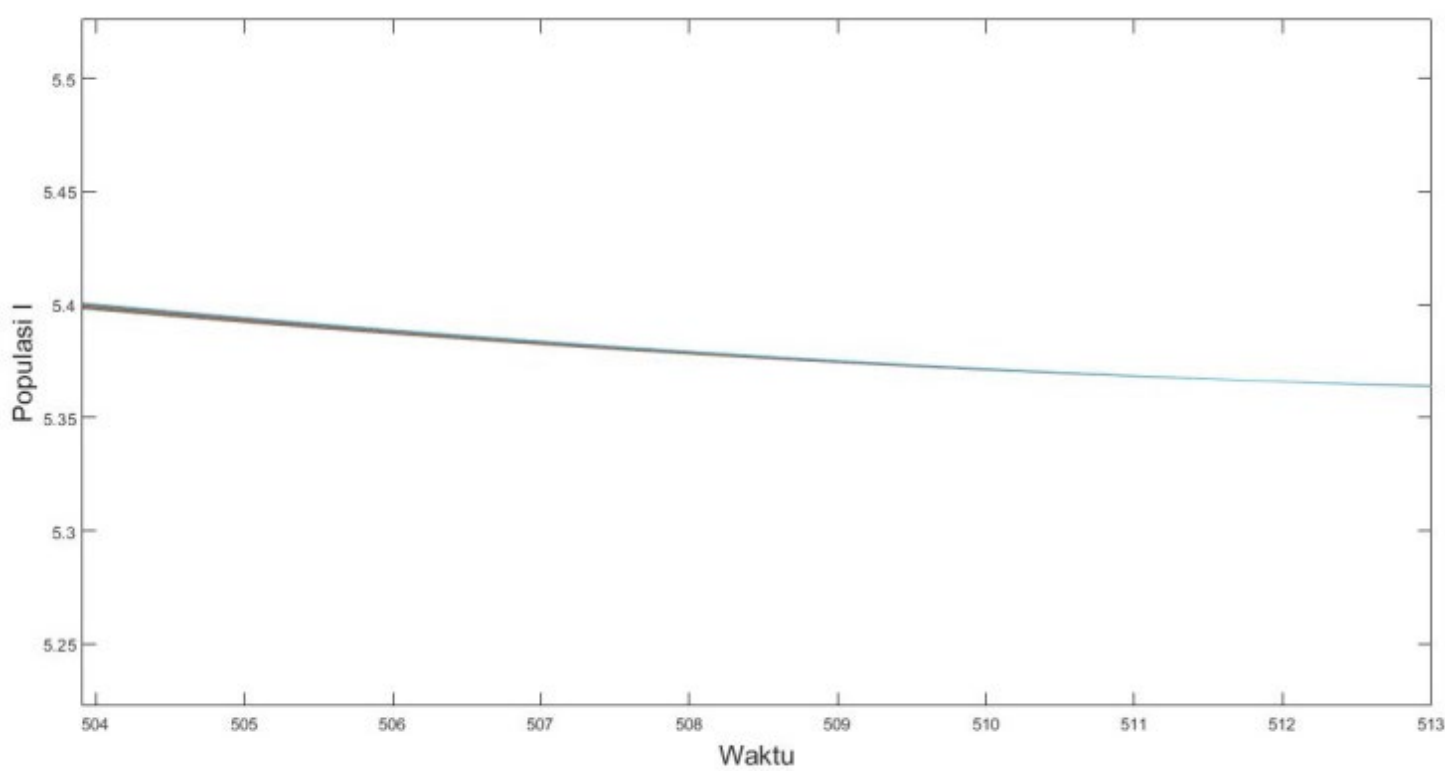

(b)

Gambar 6. Penyebaran Penyakit COVID-19 Terhadap Waktu pada Setiap Daerah di mana (a) Puncak Penyebaran, dan (b) Penyebaran Berhenti.

Ketika penyebaran penyakit COVID-19 antar daerah berhenti maka akan menunjukkan 2 (dua) kemungkinan, yaitu kemungkinan di mana tidak adanya populasi terinfeksi penyakit COVID-19 antar daerah atau kemungkinan di mana kekebalan tubuh manusia meningkat sehingga penyakit COVID-19 sudah tidak dianggap sebagai penyakit yang mematikan. 


\section{KESIMPULAN}

Adapun kesimpulan dari hasil penelitian ini adalah sebagai berikut:

1. Berdasarkan perhitungan, didapatkan persamaan travelling wave adalah sebagai berikut:

$$
\begin{aligned}
& \frac{\partial S}{\partial t}=D_{S} \frac{\partial^{2} S}{\partial x^{2}}+A-m b S I-\mu S \\
& \frac{\partial I}{\partial t}=D_{I} \frac{\partial^{2} I}{\partial x^{2}}+m b S I-\rho I-\gamma I \\
& \frac{\partial R}{\partial t}=D_{R} \frac{\partial^{2} R}{\partial x^{2}}+\rho I-\mu R
\end{aligned}
$$

2. Berdasarkan analisis travelling wave di sekitar titik tetap dari model SIR penyebaran penyakit COVID19, didapatkan kecepatan minimal gelombang penyebaran penyakit di sekitar titik tetap bebas penyakit, yaitu $c_{I}=2 \sqrt{D_{I}\left[\frac{m b A}{\mu}-\rho-\gamma\right]}=10.621 \mathrm{~km} /$ hari dan kecepatan minimal gelombang penyebaran penyakit di sekitar titik tetap endemik penyakit, yaitu $c_{I}=0 \mathrm{~km} / \mathrm{hari}$.

3. Berdasarkan simulasi yang dilakukan, pada titik tetap bebas penyakit tidak terjadi peningkatan Berdasarkan simulasi yang dilakukan, di sekitar titik tetap bebas penyakit atau daerah bebas penyakit akan terjadi travelling wave jika daerah bebas penyakit mendapatkan infeksi dari luar daerah dan penyebaran penyakit COVID-19 antar daerah dapat dikatakan cukup cepat. Sedangkan di sekitar titik tetap endemik penyakit atau daerah endemik penyakit, tidak terjadi travelling wave karena jumlah individu terinfeksi pada setiap daerah cenderung sama sehingga dapat dikatakan tidak ada penyebaran penyakit COVID-19 antar daerah. Hal tersebut menunjukkan kecepatan penyebaran penyakit COVID19 menuju daerah endemik penyakit cenderung lebih lambat dibandingkan daerah bebas penyakit.

4. Berdasarkan simulasi, puncak penyebaran penyakit COVID-19 terjadi pada hari ke-53 dan penyebaran penyakit COVID-19 mulai berhenti menyebar menuju berbagai daerah pada hari ke-510. Jika diasumsikan penyebaran penyakit COVID-19 di suatu daerah mulai pada tanggal 1 Maret 2020, maka akan mengalami puncak penyebaran pada tanggal 22 April 2020 dan mulai berhenti menyebar pada tanggal 22 Juli 2021.

\section{DAFTAR PUSTAKA}

[1] Adi, Yudi Ari and Ndii, Meksianis Z, "Modeling and Prediction of Covid-19 with A Large Scale Social Distancing", Journal Fourier, Vol. 9, no. 1, pp. 1-9, April 2020.

[2] Allman, E. S. and Rhodes, J. A, "Infectious Disease Modelling”, Mathematical Models in Biology, New York : Cambridge University Press, 2004, 281.

[3] Hariyanto, Sanjaya, S., and Suprapti, S, “Analisis Eksistensi Travelling Wave Front pada Model Matematika Reassorment Virus Influensa H5N1 dan H1N1-p”, Limits, vol. 13, no. 2, pp. 45-52, November 2016.

[4] Haqqul, M. N, Analisis Bifurkasi dan Eksistensi Travelling Wave pada Model Penyebaran Virus Ebola, PhD [Dissertation]. Surabaya, Sepuluh Nopember Institute of Technology., 2017. [Online] Available: Repository ITS.

[5] Huda, A. F., Wulan, E. R., Ilahi, F. and Khumaeroh, M. S, “Analisis Pengaruh Social Distancing pada Transmisi COVID-19 dengan Menggunakan Model SIR”, presented at KTI masa WFH LP2M, UIN Sunan Gunung Djati, Bandung. 2020.

[6] Kasbawati, “Analisis Numerik Model Epidemiologi SIR dengan Faktor Difusi,” Jurnal Matematika, Statistika, \& Komputasi, vol. 7, no. 2, pp. 98-107, Januari 2011.

[7] Puspitasari, Retna Yunita, Analisis Numerik Model Transfer Polutan di Sungai dengan Metode Forward Time Center Space. PhD [Dissertation]. Jember, Jember Universitas., 2015. [Online]. Available: Repository UNEJ.

[8] Rozi, Syamsyida, "Deskripsi dan Analisis Penyebaran Penyakit MERS Melalui Sistem Rekasi Difusi," Phytagoras, vol. 7, no. 1, pp. 9-20, April 2018.

[9] Rustan, Linda Handayani, "The Outbreak's Modeling of Coronavirus (Covid-19) Using The Modified SEIR Model in Indonesia," SPEKTRA: Jurnal Fisika dan Aplikasinya, vol. 5, Issue 1, April 2020.

[10] Shereen, M. A., Khan, S., Kazmi, A., Bashir, N. and Siddique, R, "COVID-19 Infection: Origin, Transmission, and Characteristics of Human Coronaviruses," Journal of Advanced Research, vol. 24, pp. 91-98, July 2020. 
[11] Novianty, Dythia and Lintang Siltya Utami, “Ini Dokter Pertama Laporkan Penemuan Virus COVID-19”, Wired, 30 April 2020. [Online]. Tersedia: https://www.suara.com/tekno/2020/04/30/120000/ini-dokter-pertama-laporkan-penemuan-viruscovid-19 [Diakses: 20 Juni 2020].

[12] Tahrus, Z. N. H, "Dunia dalam Ancaman Pandemi: Kajian Kesehatan dan Mortalitas Akibat COVID-19," presented at Kajian Demografi Sosial, Jakarta. 2020.

[13] Volpert, A. I., Volpert, V. A., dan Volpert, V. A, "Preface", Travelling Wave Solutions of Parabolic Systems, United State of America: American Mathematical Society, 1994, xi.

[14] Yong, B, dan Owen, L, Model Penyebaran Penyakit Menular MERS-CoV, PhD [Dissertation]. Bandung, Catholic Parahyangan University., 2015. [Online]. Available: Repository UNPAR.

[15] Yulida, Yuni dan Karim, Muhammad Ahsar, "Pemodelan Matematika Penyebaran Covid-19 di Provinsi Kalimantan Selatan," Media Bina Ilmiah, vo. 14, no. 10, Mei 2020. 